\title{
BMJ Open Facial injury management undertaken at US and UK medical treatment facilities during the Iraq and Afghanistan conflicts: a retrospective cohort study
}

\author{
John Breeze (D) , ${ }^{1,2}$ Douglas M Bowley, ${ }^{1,2}$ James G Combes, ${ }^{3}$ James Baden, ${ }^{1,2}$ \\ Rory F Rickard, ${ }^{1}$ Joseph DuBose, ${ }^{4}$ David B Powers ${ }^{5}$
}

To cite: Breeze J, Bowley DM, Combes JG, et al. Facial injury management undertaken at US and UK medical treatment facilities during the Iraq and Afghanistan conflicts: a retrospective cohort study. BMJ Open 2019;9:e033557. doi:10.1136/ bmjopen-2019-033557

- Prepublication history for this paper is available online. To view these files, please visit the journal online (http://dx.doi. org/10.1136/bmjopen-2019033557).

Received 13 August 2019 Revised 07 November 2019 Accepted 11 November 2019

Check for updates

(C) Author(s) (or their employer(s)) 2019. Re-use permitted under CC BY-NC. No commercial re-use. See rights and permissions. Published by BMJ.

${ }^{1}$ Royal Centre for Defence Medicine, Birmingham, UK ${ }^{2}$ University Hospitals Birmingham NHS Foundation Trust, Birmingham, UK

${ }^{3}$ Royal Surrey County Hospital NHS Foundation Trust, Guildford, UK

${ }^{4}$ R Adams Cowley Shock Trauma Center, Baltimore, Maryland, USA

${ }^{5}$ Duke University Medical Center, Durham, North Carolina, USA

Correspondence to

Dr John Breeze;

johno.breeze@gmail.com

\section{ABSTRACT}

Objectives To perform the first direct comparison of the facial injuries sustained and treatment performed at USA and UK deployed medical treatment facilities (MTFs) in support of the military campaigns in Iraq and Afghanistan. Setting The US and UK Joint Theatre Trauma Registries were scrutinised for all patients with facial injuries presenting alive to a UK or US deployed MTF between 1 March 2003 and 31 October 2011.

Participants US and UK military personnel, local police, local military and civilians.

Primary and secondary outcome measures An adjusted multiple logistic regression model was performed using tracheostomy as the primary dependent outcome variable and treatment in a US MTF, US or UK military, mandible fracture and treatment of mandible fracture as independent secondary variables.

Results Facial injuries were identified in 16944 casualties, with the most common being those to skin/ muscle (64\%), bone fractures $(36 \%)$, inner/middle ear $(28 \%)$ and intraoral damage (11\%). Facial injuries were equally likely to undergo surgery in US MTF as UK MTF (OR: $1.06,95 \% \mathrm{Cl} 0.4603$ to $1.142, \mathrm{p}=0.6656$ ); however, variations were seen in injury type treated. In US MTF, $692 / 1452(48 \%)$ of mandible fractures were treated by either open or closed reduction compared with $0 / 167(0 \%)$ in UK MTF $\left(\chi^{2}: 113.6 ; p \leq 0.0001\right)$. US military casualties who had treatment of their mandible fracture (open reduction and internal fixation or mandibulo-maxillary fixation) were less likely to have had a tracheostomy than those who did not undergo stabilisation of the fractured mandible (OR: $0.61,95 \% \mathrm{Cl} 0.44$ to $0.86 ; \mathrm{p}=0.0066$ ). Conclusions The capability to surgically treat mandible fractures by open or closed reduction should be considered as an integral component of deployed coalition surgical care in the future.

\section{INTRODUCTION}

In support of military operations in the Iraq and Afghanistan, the USA and UK deployed numerous military medical treatment facilities (MTFs). Their primary role was to treat coalition military forces, but as the mission evolved, treatment was offered to host nation police and military members, as well
Strengths and limitations of this study

- This is the largest analysis of patients with facial wounds treated in coalition medical treatment facility (MTF) in Iraq and Afghanistan.

- It is the first study to directly compare treatment delivered by US and UK military medical providers.

- It additionally reports data from local nationals enabling trends to be identified in which facial fractures in particular were treated.

- The lack of standardisation between the two trauma registries limits further outcome analyses between nations.

- It is not possible to collate long-term outcome data in the US system due to the lack of uniformity of reporting methods.

as the civilian population according to the prevailing 'Rules of Eligibility'. Coalition MTF deployed to Iraq and Afghanistan are broadly classified by the North Atlantic Treaty Organization into roles (or echelons). Role 1 provides primary healthcare with specialised first aid, triage, resuscitation and stabilisation. ${ }^{12}$ Role 2 MTF provide enhanced resuscitation with capability for life-saving surgery, in addition to further triage and treatment of casualties. Role 2 facilities are divided into 'Basic (R2B)', where damage control surgery (DCS) procedures can be undertaken, and 'Enhanced' (R2E) with additional capabilities and greater resources, including the capability to prepare casualties for strategic aeromedical evacuation (STRATEVAC). ${ }^{1}$ Role 3 MTF provide all the capabilities of the R2E MTF as well as the capability for specialised imaging and surgery, blood banking and laboratory support.

The US military deployed surgeons formally trained in the management of facial skeletal trauma to their role $3 \mathrm{MTF}$ at Balad (Iraq), Baghdad (Iraq) and Bagram 
(Afghanistan).${ }^{34}$ Further management of facial trauma in US military personnel occurred following STRATEVAC to Landstuhl Regional Medical Centre in Germany (role 4 ), with a proportion further evacuated to homeland US facilities (role 5). ${ }^{45}$ The UK deployed surgeons formally trained in the management of facial trauma to the R3 MTF in Camp Bastion and, for a shorter period, to the Canadian-led R3 MTF in Kandahar. ${ }^{6-9}$ Taught British practice was to repatriate patients with facial injury without stabilisation or fixation of the facial skeleton to the Royal Centre for Defence Medicine (RCDM) in Birmingham UK (role 4). ${ }^{6} 710-13$

Although both US and UK authors have previously published analyses of facial injuries sustained in Iraq and Afghanistan, comparing the results is challenging due to methodological differences. Accurate comparisons are relevant, as the US has a different approach to the UK in terms of surgical training and the range of deployed surgical specialties. This may have led to differences in the manner in which patients with facial injuries were treated. Those studies describing treatment undertaken in deployed MTF were generally based on a limited duration and/or used surgical logbooks that inevitably produce epidemiological and reporting bias. ${ }^{46-814}$ Existing papers can neither enable comparison of treatment performed at different deployed facilities, nor between population subtypes such as host nation civilians or military personnel. ${ }^{15}$ For example, between 2005 and 2010, the Canadian-led role 3 MTF at Kandahar as part of Operation ATHENA treated 184 facial fractures but did not subdivide into fracture location or patient nationality. ${ }^{9}$ Finally, the terminology used to describe the facial region has not been standardised between papers and includes 'head and neck', 'craniomaxillofacial', 'craniofacial' and 'maxillofacial'. ${ }^{17}{ }^{18}$ Analyses may include scalp and neck wounds, and these papers more often reflect the specialty of surgeon treating the wounds and not the anatomical area. ${ }^{418}$ Potential comparisons between treatment performed at US and UK MTF is enabled by both nations using databases, which record injuries using Abbreviated Injury Scale (AIS) scores. ${ }^{16} 1719$ To our knowledge, no authors have previously scrutinised the deployed trauma registries of both nations to enable direct comparisons of injuries and treatment. The aim of this analysis was therefore to compare incidence, injury types and treatment performed in Iraq and Afghanistan during the conflicts on US and UK military and host nation civilians during an extended period in order to inform future surgical skill sets and training requirements.

\section{METHODS}

All facial injuries (AIS region 2) sustained by patients between 1 March 2003 and 31 October 2011 were extracted from the US Department of Defense Trauma Registry (DoDTR) and UK Joint Theatre Trauma Registry databases. Both databases are held as spreadsheets on a secure military server in each country with highly restricted access. Institutional approval was granted from the UK Royal Centre for Defence Medicine and US Joint Trauma Registry for both interrogation of data and publication of results. These dates were chosen for analysis as during that period both the US and UK were undertaking similar combat roles and activities. The US had greater numbers of persons treated at their MTFs as they had much higher numbers of troops on the ground, reflecting the relative sizes of their military commitments. Died of wounds (DoW) was defined as casualties who died after reaching an MTF. During this period, both US and UK military units were engaged in similar types of counterinsurgency warfare and were wearing comparable types of personal armour. The Iraq conflict was described in the databases as Operation Iraqi Freedom (USA), Operation New Dawn (USA) or Operation TELIC (UK). The Afghanistan conflict was described as Operation Enduring Freedom (USA) or Operation HERRICK (UK). Population groups studied were USA, UK and other coalition military, host nation military and civilians. Host nation military primarily comprised Iraqi or Afghan National Army units. Host nation civilians included local police, such as the Afghan National Police.

Injuries in both registries were matched using AIS codes. ${ }^{20}$ Within the AIS system, the face is body region 2 and comprises the skin and soft tissues, the maxillofacial bony skeleton, eyes and ears. Frontal bone, frontal sinus, head (scalp, cranial bones and intracranial) and neck wounds were excluded from this analysis. The primary outcome measure was requirement for surgical tracheostomy as with the exception of mortality, no other measures exist for facial injuries in either database. AIS scoring of injuries in the facial region ranges from 1 to 4 and, within this system, death cannot be directly attributed to a facial injury (a score of 6 in the face and neck regions). Treatment performed in deployed US MTF was coded using the International Classification of Disease version 9 codes. Treatment performed in deployed UK MTF was coded using the Classification of Interventions and Procedures (OPCS) version 4.

Injury Severity Scores (ISS) were ISS split into terciles (tercile one $=3-15$; tercile two $=16-24$; tercile three $=25-$ $75)$. An adjusted multiple logistic regression model was performed using tracheostomy as the dependent variable and coalition casualty, ISS, mandible fracture and treatment of mandible fracture as independent variables. Reverse stepwise logistic regression was performed with a $\mathrm{p}$ value threshold of $<0.05$ for inclusion in the model. ORs were determined using a $\chi^{2}$ test with Yates' continuity correction and reported with $\mathrm{p}$ values and CI. Data analysis was performed using Stata for Mac V.15.1.

\section{RESULTS}

\section{Patient demographics and injury mechanisms}

Facial injuries were identified in 16 944/67 586 (25\%) casualties who survived to reach a deployed MTF across both databases (table 1). A total of 8792 of 16944 (52\%) 


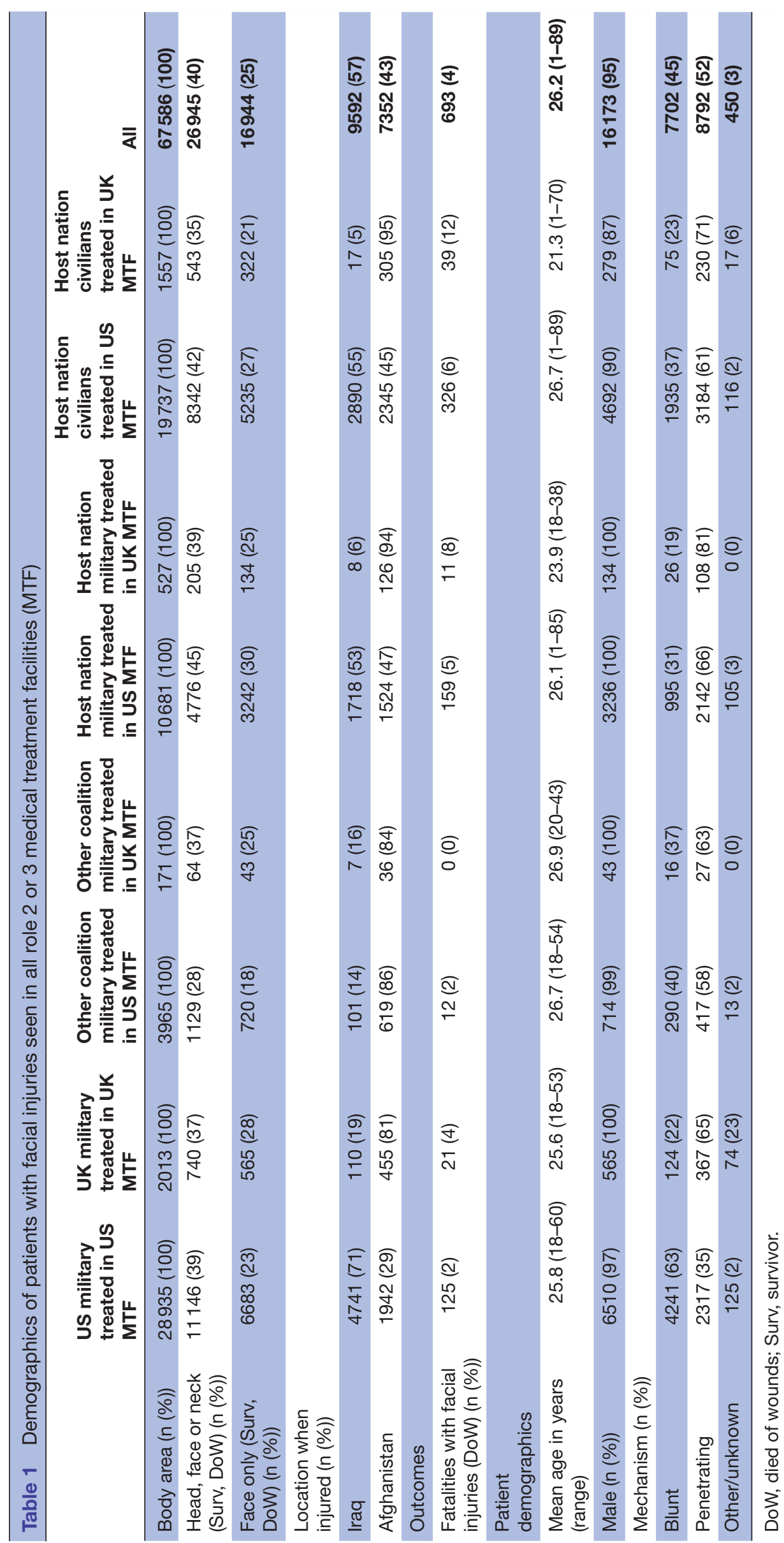


Table 2 Cause of battle and disease and non-battle injury (DNBI) in patients with a facial wound

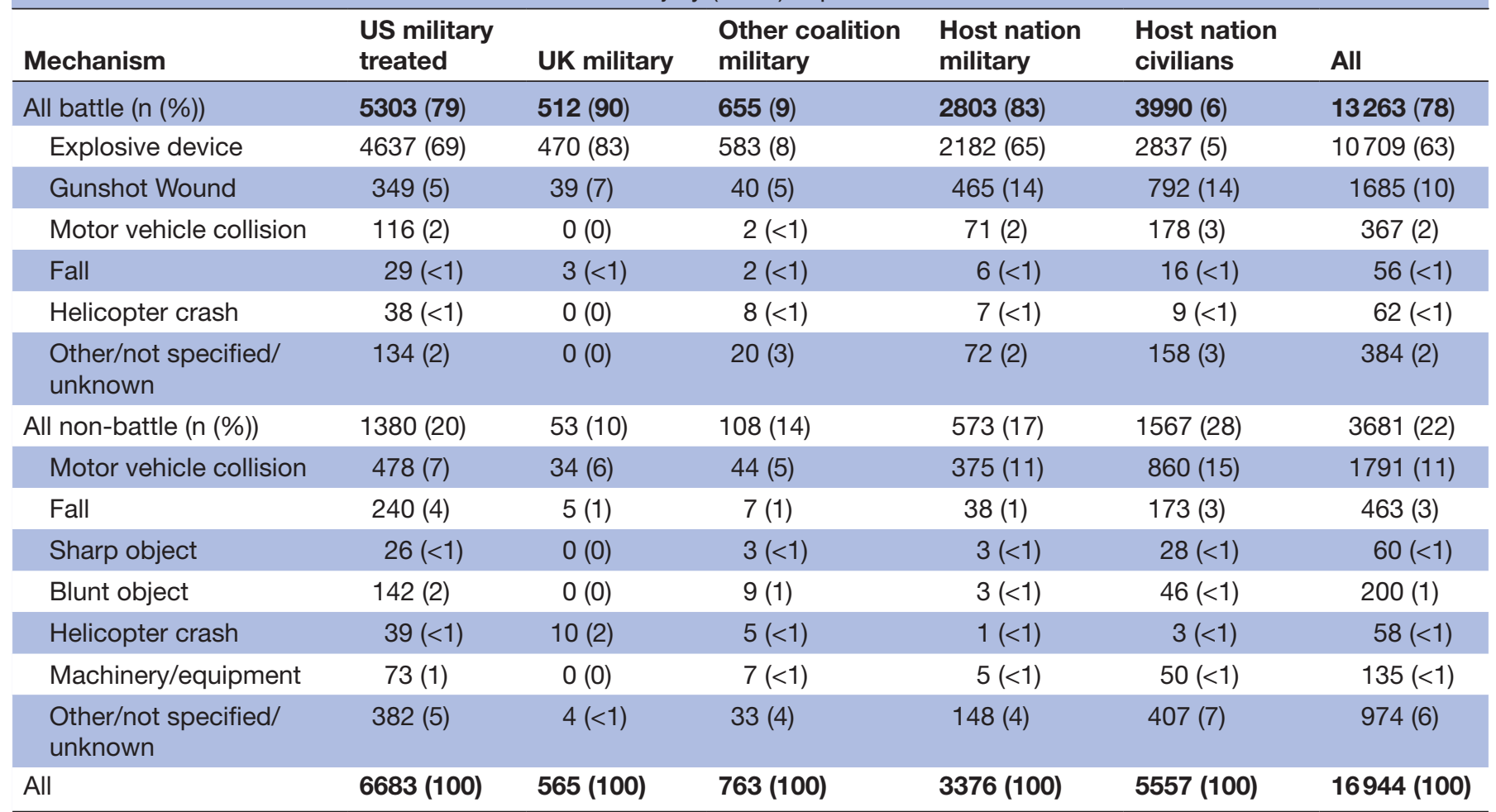

Incidences $<10$ are not shown to ensure anonymity.

were recorded as due to penetrating trauma, and 7702/16 $935(45 \%)$ from blunt trauma. The most common mechanisms of injury were explosive events (10700/16 944, $63 \%)$, motor vehicle collisions $(2158 / 16944,13 \%)$ and gunshot wounds (1685/16 944, 10\%, table 2).

\section{Types of facial injuries sustained in casualties that survived following treatment at role 2 and 3 MTFs}

A total of 693 of 16944 (4\%) patients with facial injuries who arrived alive at MTF DoW and 16 251/16 $944(96 \%)$ survived. The most common facial injuries in survivors were to skin or muscle $(10319 / 16251,64 \%)$, facial bone fractures $(5927 / 16251,37 \%)$, inner/middle ear damage $(4486 / 16251,28 \%)$ and trauma to intraoral structures including teeth $(1782 / 16251,11 \%$, table 3$)$.

\section{Treatment performed on survivors based on population cohorts}

Across both databases, 4653/16251 (29\%) of survivors had procedures undertaken for facial injuries in the deployed setting (table 4). The most common was debridement of soft tissues of skin and muscle $(3879 / 4653,83 \%)$, treatment of facial fractures $(2217 / 4653,48 \%)$ and surgical tracheostomy with facial injuries (1228/4653 (26\%). Treatment of facial fractures was divided into those managed by open reduction and internal fixation (ORIF) or those stabilised by mandibulo-maxillary fixation (MMF). A single casualty may have had both ORIF and MMF for different fractures or to a single type of fracture, hence why the totals for ORIF and MMF combined exceed the figure for either surgery alone.

\section{Treatment performed on survivors based on MTF}

Overall, patients with facial injuries were equally likely to undergo surgery in a US MTF and a UK MTF (OR: $1.06,95 \%$ CI 0.46 to $1.14, \mathrm{p}=0.6656)$. However, some variation was identified in injury type treated (figure 1). Repair of skin/muscle injuries was proportionately more commonly recorded in a UK MTF compared with a US MTF (OR: $1.465,95 \%$ CI 1.29 to 1.66 , p $\leq 0.0001$ ). Repair of intraoral injuries was more commonly recorded in a US MTF compared with a UK MTF (OR: $1.706,95 \%$ CI 1.229 to $2.375, \mathrm{p} \leq 0.0020)$. Vascular injuries were also more commonly recorded as having been treated in US MTF than UK MTF $(231 / 367,62.9 \%$ vs $19 / 42$, $45.2 \% ; \mathrm{p}=0.0301)$. However, there were more treatments recorded for facial vascular injuries in the US DoDTR than there were actual injuries recorded using AIS scores, demonstrating a discrepancy in recording. A total of 1363 of $4189(32.5 \%)$ of casualties (all patient cohorts) with facial fractures managed in US MTF were treated by ORIF or stabilised by MMF. ORIF or formal MMF was not performed in any of the 852 facial fractures seen in UK MTF. When analysing mandible fractures alone, in US MTF, 692/1452 (48\%) of mandible fractures were stabilised compared with $7 / 167(1 \%)$ in UK MTF $\left(\chi^{2}: 113.6\right.$; $\mathrm{p} \leq 0.0001)$. A total of 258 of $692(37 \%)$ of the patients with stabilised mandible fractures in US MTF were 
Table 3 Injuries to the facial region sustained in in the 16251 survivors

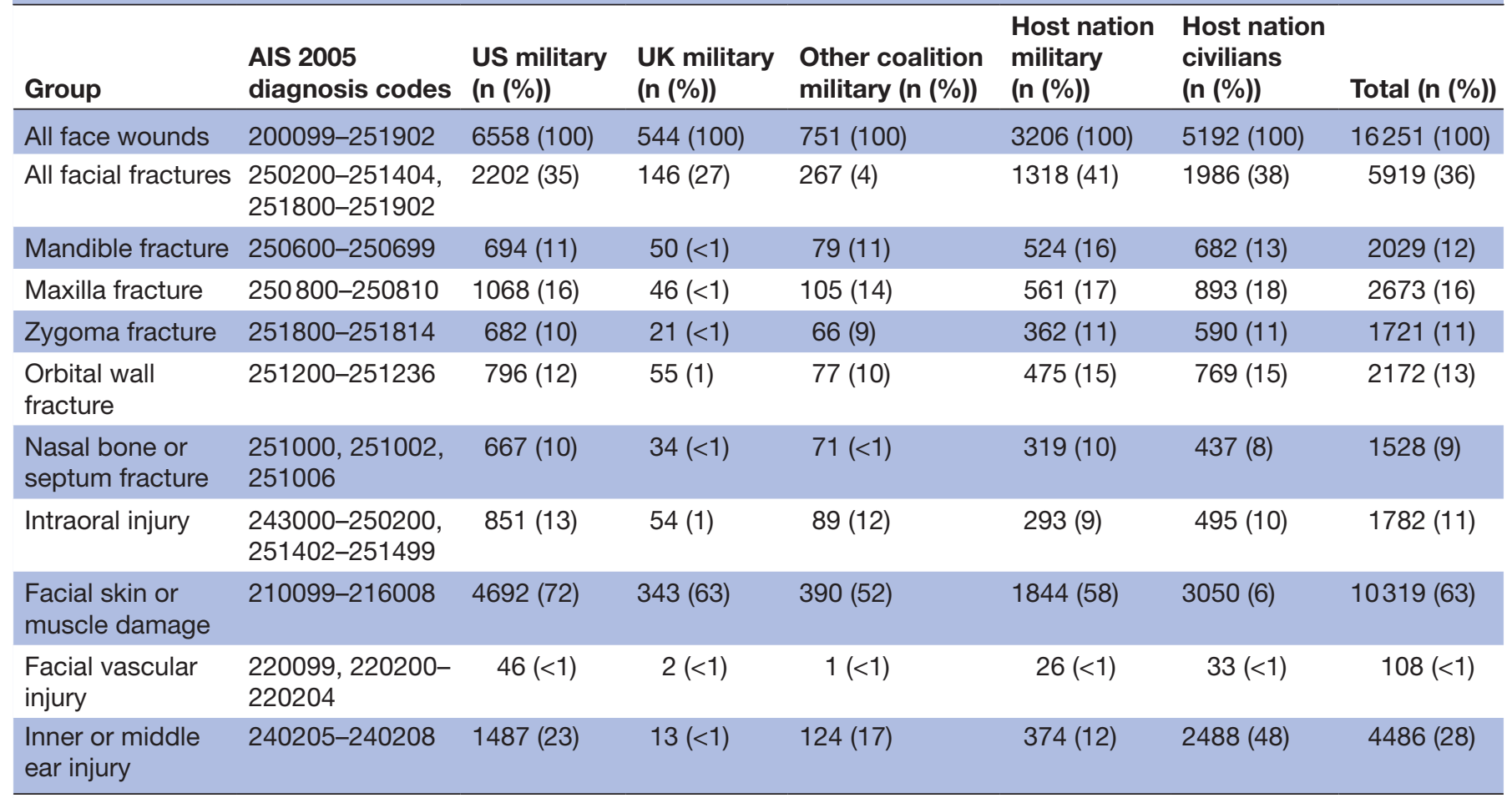

Those 693 who DoW are excluded.

AIS, Abbreviated Injury Scale; DoW, died of wounds.

treated by ORIF, while the remainder was stabilised by MMF (table 5). The seven mandible fractures temporarily stabilised in UK MTF were treated with a bridle wire (a wire spanning the teeth around a fracture). No definitive fixation was undertaken in a UK MTF.

\section{Relationship between facial fracture treatment and aeromedical evacuation}

It was not possible to accurately ascertain from the DoDTR the proportion of US military casualties with facial fractures who were evacuated; however, all UK military personnel recorded to have sustained a facial fracture underwent STRATEVAC out of theatre.

\section{Relationship between mandible fracture treatment and provision of tracheostomy}

All casualties who had a tracheostomy reported in this study had it performed prior to evacuation; however, the data cannot identify the exact temporal relation between tracheostomy and facial fracture treatment. No tracheostomies were performed for respiratory weaning. The proportion of US military survivors with mandibular fractures having tracheostomy was 250/694 (36\%) compared with $8 / 49(16 \%)$ for UK military survivors; $\chi^{2}: 6.989$; $\mathrm{p} \leq 0.0082$ (table 5). Multiple logistic regression demonstrated that the odds of requiring a tracheostomy were highest in the presence of mandible fractures (OR: 8.0, $95 \%$ CI 6.88 to $9.34, \mathrm{p}<0.001)$ and casualties treated in US MTF instead of an UK MTF (OR: 3.03, 95\% CI 2.13 to $4.32, \mathrm{p}<0.001$, table 6 ). ISS had no effect on the odds of having a tracheostomy. US military casualties who had treatment of their mandible fracture (ORIF or MMF) were less likely to have had a tracheostomy than those not treated (OR: $0.61,95 \%$ CI 0.44 to $0.86 ; \mathrm{p}=0.0066$ ).

\section{Treatment of mandible fractures in role 3 US MTF over time}

There was a distinct shift in the US management of mandible fractures over time (figure 2). There was a sharp increase in operative treatment between 2004 and 2006, and then a gradual decline. The proportion of cases managed with closed reduction fell while there was a concomitant increase in the use of ORIF, with the ratio changing from 3:2 to 1:2.

\section{DISCUSSION}

The face signals 'gender, age, social and familial identity, ethnicity, emotion and much more besides.$^{21}$ In the immediate aftermath of the First World War, injury to the face with facial disfigurement was described in the lay press as 'the worst loss of all. ${ }^{22}$ In the Times History of WWI published in 1916, soldiers with facial injury and disfigurement were described as 'the most tragic of all war's victims. ${ }^{23}$ Techniques of reconstruction are radically different today; however, highquality management of patients with facial injury remains a fundamental duty for military surgical teams. To our knowledge, this is the largest analysis of patients with facial wounds treated in coalition MTF in Iraq and Afghanistan. The study breaks new ground as 
Table 4 Overall numbers of surgical interventions performed on survivors in different casualty populations

\begin{tabular}{|c|c|c|c|c|c|c|c|}
\hline Group & $\begin{array}{l}2015 \text { ICD-9 procedure } \\
\text { codes }\end{array}$ & $\begin{array}{l}\text { OPCS-4 procedure } \\
\text { codes }\end{array}$ & $\begin{array}{l}\text { US } \\
\text { military }\end{array}$ & $\begin{array}{l}\text { UK } \\
\text { military }\end{array}$ & $\begin{array}{l}\text { Other } \\
\text { coalition } \\
\text { military }\end{array}$ & $\begin{array}{l}\text { Host nation } \\
\text { military }\end{array}$ & $\begin{array}{l}\text { Host nation } \\
\text { civilians }\end{array}$ \\
\hline $\begin{array}{l}\text { Open or closed reduction of any } \\
\text { facial fracture }\end{array}$ & & & 655 & 0 & 37 & 737 & 787 \\
\hline $\begin{array}{l}\text { Open reduction of mandible } \\
\text { fracture }\end{array}$ & 76.76 & $\begin{array}{l}\text { V15.2, V17.2, V17.8, } \\
\text { V17.9 }\end{array}$ & 258 & 0 & 8 & 179 & 404 \\
\hline $\begin{array}{l}\text { Closed reduction of mandible } \\
\text { fracture }\end{array}$ & 76.75 & V15.3, V17.2, V17.3 & 140 & 0 & 15 & 84 & 113 \\
\hline $\begin{array}{l}\text { Open or closed reduction of } \\
\text { mandible fracture }\end{array}$ & $76.75,76.76$ & $\begin{array}{l}\text { V15.1, V15.2, V15.3, } \\
\text { V15.8, V15.9, V17.3 }\end{array}$ & 385 & 0 & 22 & 242 & 499 \\
\hline $\begin{array}{l}\text { Open or closed reduction of } \\
\text { maxilla fracture }\end{array}$ & $76.73,76.74$ & $\begin{array}{l}\text { V08.1-V08.3, V08.8, } \\
\text { V08.9, V11.1-V11.4 }\end{array}$ & 115 & 0 & 4 & 73 & 101 \\
\hline $\begin{array}{l}\text { Open reduction of zygoma } \\
\text { fracture }\end{array}$ & $76.71,76.72$ & V09.3 & 83 & 0 & 2 & 77 & 105 \\
\hline Ligation of facial vessel & $\begin{array}{l}21.00-21.06,21.09 \\
38.12,38.62,38.82\end{array}$ & E12.1, L30.2 & 191 & 4 & 31 & 75 & 113 \\
\hline Repair of intra oral damage & $\begin{array}{l}27.43-27.61,27.69 \\
27.92-27.99\end{array}$ & $\mathrm{~F} 40.4, \mathrm{~F} 40.9$ & 560 & 7 & 45 & 174 & 267 \\
\hline Lateral canthotomy & 8.51 & $\mathrm{C} 11.6$ & 83 & 4 & 13 & 47 & 77 \\
\hline $\begin{array}{l}\text { Surgical tracheostomy with facial } \\
\text { injury }\end{array}$ & $\begin{array}{l}31.1,31.12,31.29 \\
31.74\end{array}$ & E42.1, E42.3 & 323 & 13 & 29 & 361 & 502 \\
\hline
\end{tabular}

Numbers relate to patients treated, not to individual surgical procedures.

ICD-9, International Classification of Disease version 9; OPCS, Classification of Interventions and Procedures.

it is the first to directly compare treatment delivered by US and UK military medical providers. The proportion of facial injuries was higher than in most conflicts prior to the 21st century, likely reflecting the enhanced effectiveness of helmets and body armour in reducing number and severity of head and truncal injury and wounding patterns due to the use of improvised explosive devices later in the Afghanistan conflict. ${ }^{17}{ }^{24}$ The proportion of facial wounds was higher in local civilians and local military, reflecting almost universal use of combat helmets by
US and UK military members and the use of ballistic eye protection from 2005 onwards. ${ }^{24}$ The data in this study extend to 2011 only as military permissions to access data did not extend beyond this. We acknowledge that there may be trends after date that might make a difference to the incidence of injury, in particular for the UK military, such as the introduction of the UK Mark 7 helmet at end of 2010, the patrol neck collar in $2013,{ }^{24}$ and the VIRTUS visor and mandible guard in 2015. ${ }^{25}$ Although the UK had lower volumes of facial injuries through

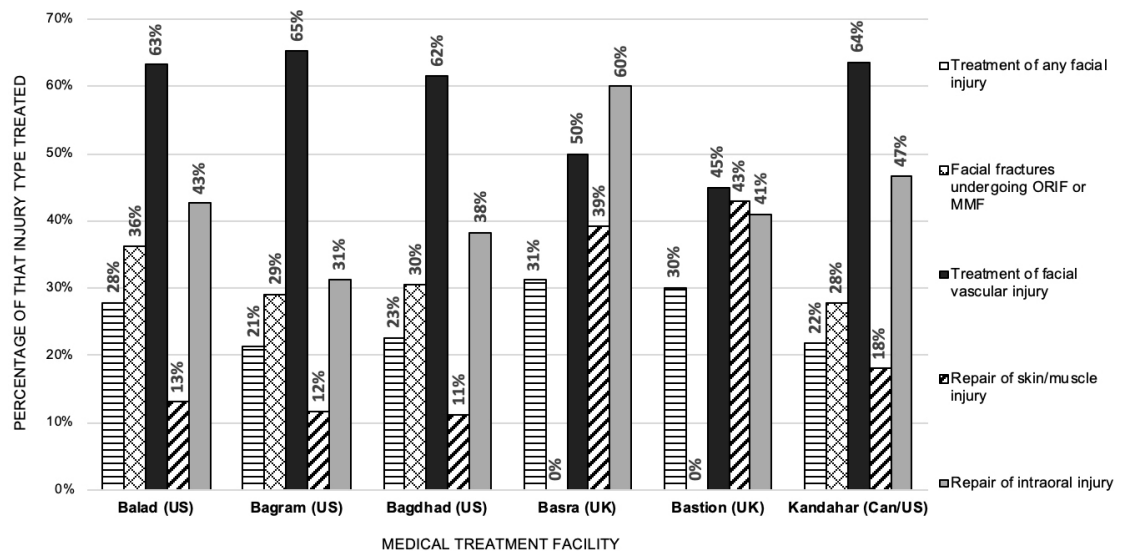

Figure 1 Proportions of different injury types found in survivors and treated according to medical treatment facility (MTF). Numbers relate to patients treated, not to individual surgical procedures. MMF, mandibulo-maxillary fixation; ORIF, open reduction and internal fixation. 
Table 5 Effect of facial fracture treatment on provision of tracheostomy in survivors to a role 3 MTF

\begin{tabular}{lll}
\hline Patient cohort & $\begin{array}{l}\text { US military (n } \\
(\%))\end{array}$ & $\begin{array}{l}\text { UK military } \\
\text { (n (\%)) }\end{array}$ \\
\hline $\begin{array}{l}\text { Survivors with mandible } \\
\text { fractures }\end{array}$ & $694(100)$ & $50(100)$ \\
$\begin{array}{l}\text { Survivors with mandible } \\
\text { fractures having } \\
\text { tracheostomy }\end{array}$ & $250 / 694(36)$ & $8 / 50(16)$ \\
$\begin{array}{l}\text { Survivors with mandible } \\
\text { fractures managed by ORIF } \\
\text { or MMF }\end{array}$ & $382 / 694(55)$ & $0 / 50(0)$ \\
$\begin{array}{l}\text { Survivors with mandible } \\
\text { fractures managed by ORIF } \\
\text { or MMF having tracheostomy }\end{array}$ & $51 / 382(13.3)$ & $0 / 50(0)$ \\
$\begin{array}{l}\text { Survivors with mandible } \\
\text { fractures not fixed having }\end{array}$ & $199 / 312(63.7)$ & $8 / 50(16)$ \\
tracheostomy & & \\
\hline
\end{tabular}

MMF, mandibulo-maxillary fixation (stabilisation); ORIF, open reduction and internal fixation (definitive treatment).

their deployed MTFs, reflecting the lower proportions of troops numbers, all evacuated coalition casualties were managed in a single level $1 /$ major trauma centre in the UK (RCDM). This has enabled consolidation of institutional knowledge and potentially optimised outcomes.

Contrast is apparent between the management of facial fractures in US versus UK MTF. The difference almost entirely related to the management of mandible fractures, with 692/1452 (48\%) stabilised in role 3 US MTF and (although 7/167 (1\%) of mandible fractures had a bridle wire placed in UK MTF), none had formal MMF or ORIF. This reflected the accepted and taught practice in UK MTF. ${ }^{196-32}$ The US Department of Defense (DoD) purposefully deployed US surgeons who regularly treated facial skeletal trauma in their day-to-day role in mainland USA. UK military plastic surgeons were deployed to the role 2E MTF at Camp Bastion from 2008 but did not repair facial fractures on coalition military or local nationals. UK military OMF surgeons deployed to the Canadian-led role 3 MTF in Kandahar from 2006 and repaired facial fractures and performed surgical tracheostomies on local nationals but only stabilised coalition military as the policy for this cohort was for rapid evacuation. Initial management of facial injury was taught to deploying UK surgical teams on the Military Operational Surgical Training predeployment course, which included stabilisation of mandibular fractures with arch-bars. ${ }^{2627}$ Complete results from Kandahar are not included in this paper as, during the date range studied, they are held in the Canadian deployed trauma care registry. However, published data demonstrated that MMF, ORIF and external fixation were performed by UK OMF surgeons in Kandahar on both local military personnel and local civilians with minimal recorded complications. ${ }^{6} 72829$ At times, UK and other individuals injured in the area of operations covered by the UK hospital at Camp Bastion who had significant cranio-facial injury were flown directly to the MTF in Kandahar to enable specialist neurosurgical care.

The sharp increase in in-theatre operative treatment of facial fractures by US forces, including the proportionally greater use of ORIF compared with closed reduction between 2004 and 2006, coincided with the publication by Lopez et al demonstrating the safety of facial fracture repair in Iraq prior to evacuation. ${ }^{30}$ Although it did not become formal US DoD policy, this principle was employed by many US deployed surgeons. The effectiveness and safety of this approach has been further confirmed in multiple studies. ${ }^{191-34}$ Such early management of facial fractures must be contrasted to those open fractures of the limbs, which most authorities agree should not be treated by open fixation early. The main stated contraindication to early definitive ORIF of facial fractures was that it would potentially delay evacuation. ${ }^{30}$ The notion that a high energy transfer wound is a contraindication to early ORIF of mandible fractures has now generally been discredited. ${ }^{35-38}$ Strong evidence exists that early management of such injuries is safe and leads to improved outcomes. ${ }^{39}$ In fact, delaying treatment of facial fractures has been demonstrated to increase patient pain, increase the likelihood of requiring a tracheostomy

Table 6 Results of multivariate logistic regression analysis with tracheostomy as dependent variable and coalition military casualty (including US and UK), ISS grouping, mandible fracture and no treatment of mandible fracture as independent variables

\begin{tabular}{|c|c|c|c|c|c|c|}
\hline Tracheostomy & OR & SE & $\mathbf{Z}$ & $P>|z|$ & $95 \% \mathrm{Cl}$ & \\
\hline Treatment in US MTF & 3.033696 & 0.5472023 & 6.15 & 0 & 2.13028 & 4.320235 \\
\hline Coalition military & 0.4257238 & 0.0292904 & -12.41 & 0 & 0.3720181 & 0.4871828 \\
\hline No treatment of mandible fracture & 0.7424999 & 0.0770788 & -2.87 & 0.004 & 0.6058057 & 0.9100379 \\
\hline ISS group 3-15 & 0.1356279 & 0.0106448 & -25.45 & 0 & 0.1162899 & 0.1581816 \\
\hline ISS group 25-75 & 1 & (omitted) & & & & \\
\hline
\end{tabular}

ISS, Injury Severity Score; MTF, medical treatment facilities. 


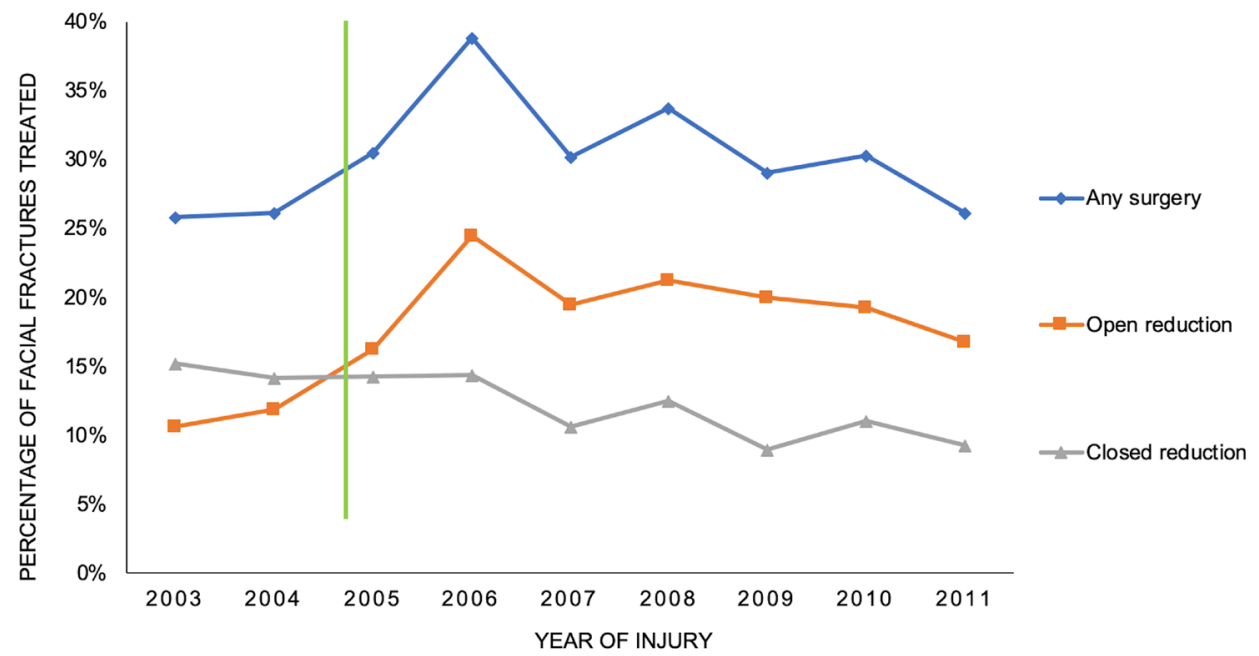

Figure 2 Proportions of all mandible fractures treated surgically over time in US medical treatment facilities. The vertical line in 2005 demonstrates when the paper by Lopez et $a{ }^{30}$ was published.

and to result in poorer outcomes for complex fractures, particularly those with avulsive soft tissue defects. ${ }^{534}$ Kittle et a $\tilde{l}^{\tilde{L}}$ demonstrated that military patients with facial fractures treated within 2 days of injury had lower complication rates and fewer returns to theatre than those left longer than 5 days for treatment back in the USA. This is particularly relevant, as our results are derived from two conflicts in which rapid evacuation of US and UK military personnel was possible, generally within 48 hours of injury. ${ }^{15} 192634$ For example, one analysis of UK military injuries during Iraq demonstrated a mean time period between injury and treatment at role 4 in Birmingham, UK of 2 days. ${ }^{40}$ The ability to achieve rapid aeromedical evacuation is predicated on coalition air dominance in the theatre of operations with rapid tactical medical evacuation from point of wounding to the role 2 or role 3 MTF (TACEVAC) and the ready availability of aircraft for strategic (out of theatre) medical evacuation (STRATEVAC). The topography and weather conditions of the Iraqi theatre of operations were generally acceptable for sustained flight operations, with air dominance obtained early in the conflict and maintained throughout the entirety of combat operations. In Afghanistan, TACEVAC was sometimes delayed due to weather conditions and altitude restrictions in mountainous regions of the country. Future conflicts are unlikely to see such rapid TACEVAC and STRATEVAC, ${ }^{26}$ and therefore treatment of facial fractures, in forward MTF, may be required to mitigate preventable morbidity.

In US MTF, treating mandible fractures prior to STRATEVAC reduced the rate of tracheostomy fivefold (from $64 \%$ to $13 \%$ ). The US rate of tracheostomy placement for mandibular fractures was 36\% compared with $16 \%$ for UK-managed cases. We accept that there are requirements for tracheostomy in a small number of patients with mandibular fractures, although clinicians at UK MTF were able to intubate the vast majority of coalition casualties prior to evacuation. However, we believe that during this period, the data match the experience of the authors, in that US military clinicians had a relatively low threshold to undertake tracheostomy. Where delay may occur in future conflicts and hence inpatient care may be required in theatre for longer, a relatively quick operation to stabilise the facial skeleton may render a patient self-ventilating, rather than requiring high-dependency care, without the need for a tracheostomy ever to be placed.

A UK military multidisciplinary consensus statement from 2018 proposed that the surgical skills required to manage facial injuries in a deployed MTF (roles 1-3) in the first 24 hours after injury are: facial vascular haemorrhage control, facial fracture stabilisation, lateral ocular canthotomy and surgical tracheostomy. This study reveals variation in the use of tracheostomy after facial injury but supports the contention that the ability to stabilise facial fractures soon after wounding offers the advantages of improved clinical outcomes and can significantly reduce the requirement for tracheostomy. The authors recognise that a major limitation of this study is the lack of standardisation between the two trauma registries, limiting further outcome analyses between nations. The components of midface fractures (zygoma, maxilla and orbit) are coded individually, but may overlap, increasing the incidence of individual fractures. In addition, it is not possible to collate long-term outcome data in the US system due to the lack of uniformity of reporting methods, no national health database and the loss of patients to the private sector once they leave, or are retired from, military service.

This is the first study to have access to both US and UK trauma databases making true comparisons between them possible. Our findings suggest that the capability to surgically treat mandible fractures by ORIF and MMF should be considered as an integral component of deployed coalition surgical care in the future. 
Contributors Substantial contributions to the conception or design of the work; or the acquisition, analysis or interpretation of data for the work: all authors. Drafting the work or revising it critically for important intellectual content: all authors. Final approval of the version to be published: all authors. Agreement to be accountable for all aspects of the work in ensuring that questions related to the accuracy or integrity of any part of the work are appropriately investigated and resolved: all authors.

Funding The authors have not declared a specific grant for this research from any funding agency in the public, commercial or not-for-profit sectors.

Competing interests None declared.

Patient consent for publication Not required.

Ethics approval Ethical approval was not required as this was a retrospective epidemiological study in which all data have been anonymised and no patient identifiable data were included. Approval for this study was granted by the Research and Innovation Department of the Royal Centre for Defence Medicine.

Provenance and peer review Not commissioned; externally peer reviewed.

Data availability statement Data may be obtained from a third party and are not publicly available.

Open access This is an open access article distributed in accordance with the Creative Commons Attribution Non Commercial (CC BY-NC 4.0) license, which permits others to distribute, remix, adapt, build upon this work non-commercially, and license their derivative works on different terms, provided the original work is properly cited, appropriate credit is given, any changes made indicated, and the use is non-commercial. See: http://creativecommons.org/licenses/by-nc/4.0/.

ORCID iD

John Breeze http://orcid.org/0000-0002-2352-1365

\section{REFERENCES}

1 Ministry of Defence. Allied Joint Publication-4.10(B). Allied Joint Doctrine for Medical Support, 2015. Available: https://assets. publishing.service.gov.uk/government/uploads/system/uploads/ attachment_data/file/457142/20150824-AJP_4_10_med_spt_uk.pdf

2 Bricknell M. For debate: the operational patient care pathway. $J R$ Army Med Corps 2014;160:64-9.

3 Chan RK, Siller-Jackson A, Verrett AJ, et al. Ten years of war: a characterization of craniomaxillofacial injuries incurred during operations enduring freedom and Iraqi freedom. $J$ Trauma Acute Care Surg 2012;73:S453-8.

4 Powers DB. Distribution of civilian and military maxillofacial surgical procedures performed in an air force theatre Hospital: implications for training and readiness. J R Army Med Corps 2010;156:117-21.

5 Kittle CP, Verrett AJ, Wu J, et al. Characterization of midface fractures incurred in recent wars. J Craniofac Surg 2012;23:1587-91.

6 Breeze J, Monaghan AM, Williams MD, et al. Five months of surgery in the multinational field hospital in Afghanistan with an emphasis on oral and maxillofacial injuries. J R Army Med Corps 2010;156:125-8.

7 Breeze J, Gibbons AJ, Combes JG, et al. Oral and maxillofacial surgical contribution to 21 months of operating theatre activity in Kandahar field Hospital: 1 February 2007-31 October 2008. Br J Oral Maxillofac Surg 2011;49:464-8. Sep.

8 Maitland L, Lawton G, Baden J, et al. The role of military plastic surgeons in the management of modern combat trauma: an analysis of 645 cases. Plast Reconstr Surg 2016;137:717e-24.

9 Brisebois R, Hennecke P, Kao R, et al. The role 3 multinational medical unit at Kandahar Airfield 2005-2010. Can J Surg 2011;54:S124-9.

10 Breeze J, Gibbons AJ, Opie NJ, et al. Maxillofacial injuries in military personnel treated at the Royal centre for defence medicine June 2001 to December 2007. J Oral Maxillofac Surg 2010;48:613-6.

11 Wordsworth M, Thomas R, Breeze J, et al. The surgical management of facial trauma in British soldiers during combat operations in Afghanistan. Injury 2017;48:70-4.

12 Breeze J, Gibbons AJ, Hunt NC, et al. Mandibular fractures in British military personnel secondary to blast trauma sustained in Iraq and Afghanistan. Br J Oral Maxillofac Surg 2011;49:607-11.
13 Breeze J, McVeigh K, Lee JJ, et al. Management of maxillofacial wounds sustained by British service personnel in Afghanistan. Int $J$ Oral Maxillofac Surg 2011;40:483-6.

14 Brennan J. Experience of first deployed otolaryngology team in operation Iraqi freedom: the changing face of combat injuries. Otolaryngol Head Neck Surg 2006;134:100-5.

15 Lew TA, Walker JA, Wenke JC, et al. Characterization of craniomaxillofacial battle injuries sustained by United States service members in the current conflicts of Iraq and Afghanistan. J Oral Maxillofac Surg 2010;68:3-7.

16 Wade AL, Dye JL, Mohrle CR, et al. Head, face, and neck injuries during operation Iraqi freedom II: results from the US Navy-Marine Corps combat trauma registry. J Trauma 2007;63:836-40.

17 Breeze J, Gibbons AJ, Shieff C, et al. Combat-Related craniofacial and cervical injuries: a 5-year review from the British military. $J$ Trauma 2011;71:108-13.

18 Xydakis MS, Fravell MD, Nasser KE, et al. Analysis of battlefield head and neck injuries in Iraq and Afghanistan. Otolaryngol Head Neck Surg 2005;133:497-504.

19 Feldt BA, Salinas NL, Rasmussen TE, et al. The joint facial and invasive neck trauma (J-FAINT) project, Iraq and Afghanistan 20032011. Otolaryngol Head Neck Surg 2013;148:403-8.

20 Champion HR, Holcomb JB, Lawnick MM, et al. Improved characterization of combat injury. J Trauma 2010;68:1139-50.

21 Biernoff S. The rhetoric of disfigurement in first World War Britain. Social History of Medicine 2011;24:666-85.

22 Worst Loss Of All. Manchester evening chronicle; 1918.

23 History of the war. The Times; 1916.

24 Breeze J, Allanson-Bailey LC, Hepper AE, et al. Novel method for comparing coverage by future methods of ballistic facial protection. Br J Oral Maxillofac Surg 2015;53:3-7.

25 Breeze J. The problems of protecting the neck from combat wounds. J R Army Med Corps 2010;156:137-8.

26 Breeze J, Blanch R, Baden J, et al. Skill sets required for the management of military head, face and neck trauma: a multidisciplinary consensus statement. J R Army Med Corps 2018;164:133-8.

27 Breeze J, Combes JG, DuBose J, et al. How are we currently training and maintaining clinical readiness of US and UK military surgeons responsible for managing head, face and neck wounds on deployment? J R Army Med Corps 2018;164:183-5.

28 Gibbons AJ, Mackenzie N, Breederveld RS. Use of a custom designed external fixator system to treat ballistic injuries to the mandible. Int J Oral Maxillofac Surg 2011;40:103-5.

29 Gibbons A, N M, Mackenzie N. Lessons learned in oral and maxillofacial surgery from British military deployments in Afghanistan. J R Army Med Corps 2010;156:113-6.

30 Lopez MA, Arnholt JL. Safety of definitive in-theater repair of facial fractures. Arch Facial Plast Surg 2007;9:400-5.

31 Faulkner JA, Ferguson EE. Innovations in military handling of facial trauma. J Craniofac Surg 2009;20:62-7.

32 Keller MW, Han PP, Galarneau MR, et al. Characteristics of maxillofacial injuries and safety of in-theater facial fracture repair in severe combat trauma. Mil Med 2015;180:315-20.

33 Brennan J. Head and neck trauma in Iraq and Afghanistan: different war, different surgery, lessons learned. Laryngoscope 2013;64:n/a-7.

34 Zachar MR, Labella C, Kittle CP, et al. Characterization of mandibular fractures incurred from battle injuries in Iraq and Afghanistan from 2001-2010. J Oral Maxillofac Surg 2013;71:734-42.

35 Girotto JA, MacKenzie E, Fowler C, et al. Long-Term physical impairment and functional outcomes after complex facial fractures. Plast Reconstr Surg 2001;108:312-27.

36 Gruss JS, Antonyshyn O, Phillips JH. Early definitive bone and softtissue reconstruction of major gunshot wounds of the face. Plast Reconstr Surg 1991;87:436-50.

37 Motamedi MHK. Primary management of maxillofacial hard and soft tissue gunshot and Shrapnel injuries. J Oral Maxillofac Surg 2003;61:1390-8.

38 Vayvada $\mathrm{H}$, Menderes A, Yilmaz M, et al. High-Energy shotgun and rifle wounds to the face. J Craniofac Surg . 2005;16:794-804 http:// www.ncbi.nlm.nih.gov/pubmed/16192858

39 Peled M, Leiser Y, Emodi O, et al. Treatment protocol for high velocity/high energy gunshot injuries to the face. Craniomaxillofac Trauma Reconstr 2012;05:031-40.

40 Blanch RJ, Bindra MS, Jacks AS, et al. Ophthalmic injuries in British armed forces in Iraq and Afghanistan. Eye 2011;25:218-23. 